Article

\title{
An Assessment of Material Waste Disposal Methods in the Nigerian Construction Industry
}

\author{
Olabode Emmanuel Ogunmakinde * ${ }^{(\mathbb{C}}$, William Sher and Kim Maund $(\mathbb{D}$
}

School of Architecture and Built Environment, University of Newcastle, Callaghan, New South Wales 2308, Australia; Willy.Sher@newcastle.edu.au (W.S.); Kim.Maund@newcastle.edu.au (K.M.)

* Correspondence: olabode.ogunmakinde@uon.edu.au; Tel.: +61-415815561

Received: 12 February 2019; Accepted: 15 March 2019; Published: 19 March 2019

check for updates

\begin{abstract}
The construction industry is faced with many challenges, among which is waste management. Aside from the fact that wastage contributes to time and cost overrun, it also has environmental implications in the form of pollution. However, the industry has the capacity to effectively manage waste, from generation to disposal. All stages of the management process are important, but scholars and governments have provided the final step, being disposal, unabated attention in order to ensure effective management. Potential waste disposal methods, including incineration, burning, landfilling, recycling, reuse, open dumping, pyrolysis, and shredding have emerged from the literature around the globe. Despite various waste minimisation and sustainable disposal options that are available, construction material waste is still increasing in Nigeria, while disposal remains a major issue for firms and government. Therefore, this study assesses disposal methods among construction firms to determine whether there is a relationship between their practices towards waste disposal. The research followed a concurrent triangulation design in a cross sectional survey, while data were collected via a convergent parallel mixed methods. The quantitative phase employed a structured questionnaire to collect data from 243 building construction firms, while the qualitative phase involved semi-structured interviews with 65 professionals from 10 on-going construction projects in Lagos, Nigeria. The research revealed that landfilling is the most common method of waste disposal, which is closely followed by reuse as backfill and recycling. In addition, the study revealed no association between company's ownership statuses, age, project specialisation, and disposal methods, except company's size. In conclusion, the study establishes the need for regulatory policies, such as site waste management plan (SWMP), pay as you throw (PAYT), and landfill ban, which would minimise material waste and divert them from landfills. Recycling and reuse are recommended as sustainable approaches for waste disposal.
\end{abstract}

Keywords: construction waste; disposal; Nigeria; waste management; triangulation design

\section{Background of the Study}

Waste management has become an important issue confronting both developed and developing countries. The rate of waste generation has continued to increase, due to population growth, lifestyle choices, consumption, and technological advancement [1], which has strengthened the need to address this environmental concern. Waste generation varies from one sector of the economy to another; however, the construction industry is a generator of a significant volume of waste. For instance, construction waste represents $40 \%$ of total solid waste that is generated in Canada, 35\% in Brazil, and $65 \%$ in Hong Kong [2-4]. In the United Kingdom (UK), construction waste represents 13\% [5], while it is about 33.3\% in Finland [6]. These wastes are by-products that arise from construction activities, such as renovation, demolition, maintenance, and civil engineering works [7]. However, they vary in terms 
of sizes, components, and types. According to Ekanayake and Ofori [8], construction waste types are material, labour, and machinery, with material waste being mostly generated.

Material wastes are those that are considered to be useless for construction purposes and they are disposed of [9]. Similarly, Garba, Olaleye, and Jibrin [10] described material waste as those that contribute no value to the construction project and that have been recognised as a major challenge to the industry due to their negative effects. Several studies (see, for example, [11-13]) have identified the impacts of material wastage to include pollution, resource depletion, climate change, and energy consumption. The other effects are time overrun, cost overrun, and a source of dispute [14-16]. The causes of material waste are diverse and they may depend on several factors, including construction method, attitudes of the construction workforce, materials employed, and site conditions. Many researchers (see, for example, [17-20]) have identified a range of causative factors within the context of this research; however, it is those that were identified by Odusami, Oladiran, and Ibrahim [21] that are applicable to this study. They identified 22 causes of waste, which were categorised into six factors, namely: client related, management related, supply and storage related, design related, construction related, and phenomenal occurrences. Consistent among these causes are design changes, poor supervision, and material handling, which are human induced and may be minimised by adopting appropriate waste management strategies [22-24].

Waste management is a vital part of construction [25]: where the aim is to reduce and repurpose the quantity of waste generated, respectively. The intent is to achieve sustainable construction practices through social, environmental, and economic principles that contribute to sustainable development. The predominant stages in managing waste are generation, storage, collection, transfer, processing, and disposal [26], where several approaches may be adopted during each stage to ensure effective management. Although waste generation may be inevitable, reduction is possible and it may be achieved throughout all construction activities, from design to deconstruction. Previous studies (for example, $[9,22,27,28]$ ) have highlighted that one of the most appropriate strategies for managing waste is to minimise them through design. If less waste initially is generated, then there will be less pressure on other stages in the management process. Conversely, the final stage-disposal—the focus of this study is fundamental in determining the success and effectiveness of the entire management process, because poor and indiscriminate waste disposal would constitute environmental degradation. Therefore, it is important to carefully select and adopt disposal methods that are environmental friendly for construction material wastes due to their invaluable characteristics that could serve as resources for other industries $[29,30]$.

Waste disposal methods that were identified from the literature include: recycling, incineration, composting, landfilling, open dumping, burning, reuse, shredding, and pyrolysis [31-36]. Recycling is described as the end-of-life recovery of a material's value and its reprocessing into a new product for continuous usage in its primary or secondary state [31,37]. Through recycling, the consumption of finite resources is reduced [38-40], while the potential resources are conserved. However, its disadvantages include neglect of product's quality and efficiency [41] and the lack of energy recovery [42,43]. Incineration disposes wastes by means of combustion at high temperature [32], which could be through the central system or on-site. The advantages of incineration are waste reduction, production of electricity, and heat energy [33], while the disadvantages include pollution in the form of acid rain and ash production [32]. Composting employs the natural microbial organisms in organic waste decomposition [33]. It contributes to global warming being aerobic by producing carbon dioxide, glass like residue, and plastics [44].

According to Kamalan et al. [34], landfill is described as a designated space on the earth's surface where waste materials are buried. Usually, landfills are for a specific period of time and comprise two types, which are sanitary and natural attenuation [45]. Its advantages include job opportunities for scavengers and energy generation from the gases produced. Landfills used to be the cheapest and most economical method of waste disposal, but its negative effects on the environment makes it unsustainable [34]. For example, leachates are produced, which causes ground water contamination 
and air pollution. There are other social and health effects of landfill, which makes it practically less effective for managing construction wastes. Open dumping is another cheap disposal method, where wastes are carelessly dumped in open spaces, such as road side kerbs and corner areas on sites [46]. Aside from the fact that it is a cheap option, there are no advantages of this method; however, there is a plethora of disadvantages, including fire hazard and air-borne diseases [47]. Burning is similar to open dumping, which involves setting wastes on fire. There are risks that are associated with this option, which includes fire, explosion, and air pollution. It also contributes to ozone layer depletion through greenhouse gases that are emitted during the process.

According to den Hollander, Bakker, and Hultink [35], reuse is "any operation by which products or components that are not waste are used again for the purpose for which they were conceived" (p.518). Reuse as a disposal option ensures that wastes are reduced in an efficient manner, which is possible through direct or indirect use. Environmentally, it reduces waste, greenhouse gas emission, air pollution, and energy. It enhances social interaction and also reduces the cost of producing new materials. Pyrolysis, as an alternative to incineration, ensures the thermal decomposition of materials at very high temperatures and in the absence of oxygen [36]. It has the ability to reduce waste volume, degrade toxic components, and produce gases that can be used as fuel. On the other hand, it produces ashes that contaminate the air, thereby causing pollution. Likewise, the operational cost of pyrolysis is high making it non-economical, especially in developing countries [36]. Shredding is another waste disposal method whose purpose is to reduce waste sizes via a mechanical process. These wastes are finally disposed through other disposal methods, which implies that shredding is a means to an end and not an end itself. It is obvious that, aside from reuse and recycling, other waste disposal methods are not environmental friendly and, as such, it can be concluded that they are unsustainable.

The need to dispose waste in an efficient manner is very pressing for many developing countries, including Nigeria, where the generation rate of construction material waste has been reported to be high, and disposal methods, less sustainable. For example, Akanni [48] reported 13.6\% material wastage, while Adewuyi, Idoro, and Ikpo [49] revealed that material wastage exceeds the estimator's allowance. Despite the high levels of material waste, Wahab and Lawal [50] observed that little attention is given to construction waste in Nigeria and argued that a low means of disposal and the lack of awareness may be responsible. In support of their observation, Kareem, Asa, and Lawal [51] further explained that the high volume of wastes are due to the availability of inexpensive disposal methods, suggesting the need for government regulatory policies and organisational policies. At the firm level, Dania et al. [52] found that waste management is generally poor, while other studies $[50,53,54]$ revealed that different disposal methods are adopted on construction sites. Likewise, previous studies $[21,48,49,52]$ have assessed construction waste management from firms' perspective, but did not indicate the effect of company's characteristics on the choice of disposal methods.

According to the Lagos State Waste Management Authority (LAWMA) [55], there are five landfill sites (three major sites and two temporary sites) in the state, where all types of waste (including construction) are disposed. The recycling of construction waste in Lagos has been described to be very low [56], while some household wastes (such as plastics and papers) are recycled to some extent [55]. Additionally, burning and burying are quite common in Lagos [56]. A study by Obadina [57] found that the reuse of some waste material is possible, however Odewumi [58] noted that they have been under-utilised. Incineration, on the other hand, is not commonly practiced in Lagos and Nigeria as a whole [59]. It is against this backdrop that this study assessed construction material waste disposal methods that are based on seven methods, including landfill, burning, recycling, reuse as backfill, on site dig and bury, open dumping, and incineration identified from the literature.

Therefore, the aim of this study was to assess and determine the relationship between material waste disposal methods and the characteristics of Nigerian building construction firms, with a view to proffering sustainable options. In order to achieve the aim, the objectives are:

1. identifying material wastes disposal methods; 
2. determining whether a relationship exists between company characteristics and disposal methods; and,

3. recommending sustainable alternatives.

\section{Study Area and Research Methodology}

This study focuses on the building sector of the Nigerian construction industry due to its predominant traditional method of construction, which has tendencies to generate significant waste. The research was conducted in Lagos State, Nigeria and the rationale for the selection were: (a) approximately $60 \%$ of construction activities in Nigeria take place in Lagos [60]; (b) it is the commercial nerve centre and the former capital of the country; and, (c) about $70 \%$ of construction firms in Nigeria are physically present in Lagos [61].

\subsection{Research Design}

Based on the aim of this study, the research was designed to assess, report, and provide meaning to data on waste disposal. A convergent parallel mixed methods, where both quantitative and qualitative approaches employed in a single enquiry, was adopted for this study. The purpose was specifically for triangulation, while data were collected once (cross-sectional). The research design followed the concurrent triangulation design that was recommended by Creswell, Plano Clark, Gutmann, and Hanson [62], where data were collected and analysed simultaneously and the results were compared (Figure 1). For this study, quantitative data were collected and analysed through survey questionnaire and descriptive statistics, while qualitative data employed semi-structured in-depth interviews and thematic analysis, respectively.

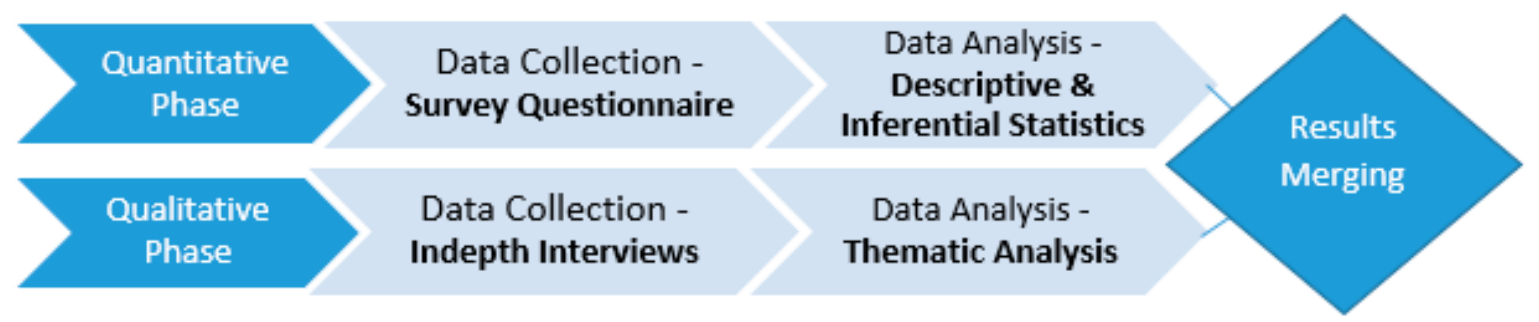

Figure 1. Concurrent Triangulation design. Source: Adapted from Creswell et al. [57].

\subsection{Research Materials}

A review of extant literature on construction waste disposal methods was conducted while using databases, such as Scopus, Web of Science, and Google Scholar. Seven disposal methods that were identified from the literature [50,52,63-65] were employed for the survey. Data were collected through a questionnaire survey and interviews.

\subsection{Research Participants}

The participants in this study were building construction firms and professionals with a minimum of three years' experience in the building sector. They included: architects, quantity surveyors, project managers, engineers, foremen, main contractors, and sub-contractors. These professionals have requisite knowledge, as they are connected to material waste on construction projects. Through a simple random sampling, building construction firms that were recruited for this study were identified from Vconnect, an online register of companies in Nigeria that is available at www.vconnect.com. The register had 2684 building construction firms in Lagos and with the help of Cochran's sample size formula [65], 337 companies were selected. To achieve the sample size (337), 700 questionnaires were emailed to organisations and 30 were randomly administered face-to-face. Construction professionals were identified through a purposive selection of 10 on-going building construction projects in Lagos involving all aforementioned professionals and a total of 70 participants were surveyed. These construction 
projects were purposively selected based on their level of completion, availability, and involvement of construction professionals. The firms were categorised into small, medium, and large based on their annual turnover, as adopted by previous studies [59-61,66-68]. Furthermore, company characteristics, such as ownership status, age, size, and area of specialisation were adopted for this study.

\subsection{Research Procedure}

The questionnaire survey included closed-ended questions that were administered online and face-to-face. The former consisted of a web link to the online form, which was emailed to randomly selected building construction firms, while the latter comprised printed copies that were hand delivered. The questionnaire requested information regarding respondents, their organisations, and waste disposal methods. For the purpose of privacy and confidentiality, the participants and organisations were de-identified/assigned codes. Semi structured in-depth interviews were also conducted to uncover rich data in terms of opinions and experiences of participants on the subject. As the most common method for collecting qualitative data [69], it consists of guided open-ended questions to capture participants' verbal and non-verbal responses and to keep focus. The quantitative data were analysed by means of descriptive statistics, such as frequency and percentages via the Statistics Package for the Social Sciences (SPSS v.24). With the help of NVivo 11, qualitative data were analysed through thematic analysis.

\section{Findings and Discussion}

\subsection{Response Rate}

The sample size for the quantitative phase of this study was 337; however, 700 questionnaires were emailed to organisations with 30 being administered face-to-face. Overall, 730 questionnaires were administered, 464 were returned, and only 243 were duly completed and found to be usable, which represents a $33.3 \%$ response rate. Generally, a low response rate is common with surveys in construction management, and some researchers [70-73] have reported $20-30 \%$ as the norm. For example, a study that was conducted by Tam [74] reported a response rate of 31.2\%, Chinowsky and Meredith reported $26.5 \%$ [75], while Fahmy, Hassan, and Bassioni [76] reported a $4.1 \%$ response rate.

For the qualitative phase, 65 interviews were conducted with participants from 10 building construction projects. Table 1 shows the details of interviewees. In addition, an authority from the agency that is responsible for waste collection and disposal was interviewed.

Table 1. Interviewees and projects' details.

\begin{tabular}{|c|c|c|c|c|c|c|c|c|c|}
\hline PC & Project Type and Location & A & $\mathrm{E}$ & $\mathbf{F}$ & MC & PM & QS & SC & Total \\
\hline S1 & Religious, Ikoyi & $\checkmark$ & $\checkmark$ & $\checkmark$ & $\checkmark$ & $\checkmark$ & $\checkmark$ & $\checkmark$ & 7 \\
\hline S2 & Residential, Ajah & $x$ & 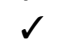 & $d$ & 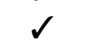 & 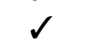 & 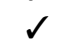 & 2 & 6 \\
\hline S3 & Commercial, Victoria Island & $\checkmark$ & $\checkmark$ & $\checkmark$ & $\checkmark$ & $\mathrm{x}$ & $d$ & $\checkmark$ & 6 \\
\hline S4 & Residential, Ikoyi & $\checkmark$ & $\checkmark$ & $\checkmark$ & $\checkmark$ & $\checkmark$ & $\checkmark$ & $\checkmark$ & 7 \\
\hline S5 & Commercial, Lekki & $\checkmark$ & $\checkmark$ & $\checkmark$ & $\checkmark$ & $\checkmark$ & $\mathrm{x}$ & $\checkmark$ & 6 \\
\hline S6 & Religious, Yaba & $\checkmark$ & $\checkmark$ & $\mathrm{x}$ & $\checkmark$ & $\checkmark$ & $\checkmark$ & $\checkmark$ & 6 \\
\hline S7 & Residential, Ipaja & $\checkmark$ & $\checkmark$ & $\checkmark$ & $d$ & $d$ & $d$ & 2 & 7 \\
\hline S8 & Recreation/Entertainment, Ikeja & $\checkmark$ & $\checkmark$ & $\checkmark$ & $\checkmark$ & $\checkmark$ & $\checkmark$ & $\checkmark$ & 7 \\
\hline S9 & Mixed (Commercial \& Residential), Ikeja & $\checkmark$ & $\checkmark$ & $\checkmark$ & $\checkmark$ & $\checkmark$ & $\mathrm{x}$ & $\checkmark$ & 6 \\
\hline \multirow{2}{*}{ S10 } & Commercial, Ikoyi & $\checkmark$ & $\checkmark$ & $\checkmark$ & $\checkmark$ & $\checkmark$ & $\checkmark$ & $\checkmark$ & 7 \\
\hline & Total & 9 & 10 & 9 & 10 & 9 & 8 & 10 & 65 \\
\hline
\end{tabular}

PC—Project code, S-Site, A-Architects, E-Engineers, F-Foremen, MC—Main Contractors, PM-Project Managers, QS-Quantity Surveyors, SC-Sub-Contractors.

\subsection{Respondents and Organisations' Characteristics}

Tables 2 and 3 present respondents' and organisations' characteristics for the quantitative phase of the study, respectively, while Table 4 details interviewees' characteristics. The demographic data 
highlighted that a range of professionals and top management staff of construction firms were represented, which gave a good cross-section of opinions. In addition, the data indicated that the participants possessed educational qualifications and experience that are required to provide necessary information for the study. The majority of construction firms surveyed are privately owned and have been operating for more than 21 years. They are majorly small scale firms that specialises in new builds. These characteristics provide insight into waste disposal methods that are adopted by firms and whether it differs.

Table 2. Respondents' profile.

\begin{tabular}{ccc}
\hline \multicolumn{3}{c}{ Respondents' Job Description } \\
\hline & Frequency & Percentage \\
Urban planner & 1 & 0.4 \\
CEO & 14 & 5.8 \\
Manager & 7 & 2.9 \\
Project Manager & 40 & 16.5 \\
Architect & 88 & 36.2 \\
Engineer & 25 & 10.3 \\
Contract/Quality Manager & 2 & 0.8 \\
Quantity Surveyor & 53 & 21.8 \\
Builder & 11 & 4.5 \\
Technician & 2 & 0.8 \\
\hline Level of Educational & \\
\hline Ordinary National Diploma & 2 & 0.8 \\
Higher National Diploma & 30 & 12.3 \\
Post Graduate Diploma & 10 & 4.1 \\
Bachelor Degree & 78 & 32.1 \\
Master Degree & 120 & 49.4 \\
PhD & 3 & 1.2 \\
\hline
\end{tabular}

Table 3. Organisations' characteristics.

\begin{tabular}{ccc}
\hline \multicolumn{3}{c}{ Ownership Status } \\
\hline & Frequency & Percentage \\
Privately owned & 161 & 66.3 \\
Partnership & 38 & 15.6 \\
Government owned & 18 & 7.4 \\
Public Limited Company & 26 & 10.7 \\
\hline \multicolumn{3}{c}{ Age of Organisation } \\
\hline 1-5 years & 48 \\
6-10 years & 58 & 19.8 \\
11-15 years & 39 & 23.9 \\
16-20 years & 34 & 16.0 \\
Above 21 years & 64 & 14.0 \\
Size of Organisation & 26.3 \\
\hline Up to N50million (Small) & 114 \\
Ab1-500million (Medium) & 60 & 46.9 \\
\hline Abo1million (Large) & 69 & 24.7 \\
Area of Project Specialisation \\
\hline New build & 208 \\
Maintenance/repair & 17 & 85.6 \\
Renovation & 14 & 7.0 \\
Demolition/deconstruction & 4 & 1.6 \\
\hline
\end{tabular}


Table 4. Interviewees' characteristics.

\begin{tabular}{cc}
\hline \multicolumn{2}{c}{ Experience } \\
\hline Years of experience & No of Interviewees \\
\hline 3-5 years & 16 \\
$6-10$ years & 18 \\
$11-15$ years & 11 \\
$16-20$ years & 6 \\
$21-25$ years & 6 \\
26-30 years & 4 \\
Above 31 years & 4 \\
Average years & 13.1 years \\
\hline & Educational Level \\
\hline Maximum & Masters (MSc.) \\
Minimum & Ordinary National Diploma (OND) \\
\hline
\end{tabular}

\subsection{Disposal Methods}

The results of the quantitative data reveal that landfilling, closely followed by 'reuse as backfill', and recycling, in that order, are the main disposal options (Table 5) that are adopted by building construction firms in Nigeria, while the qualitative data indicate 'cart away' by the State government's agency that is responsible for managing waste, throw away, and re-sell as the top three material waste disposal methods based on the number of mentions during interviews (Figure 2). However, a government authority through interview confirmed that material wastes that were collected from construction sites are disposed in the landfill.

"Well, if you look at construction waste in totality and peculiar to the agency's operations, you will find out that how it is being managed in other part of the world- Europe and the like is very different from our peculiarity here. The reason being that, due to the nature of our economy, waste has not been well structured in terms of sorting and for the fact that it is not well sorted out, it is being comingled and it is what we find in the container that we will pick and take to the dump site" (Government Authority).

This finding of quantitative and qualitative data support that landfilling is the main disposal method. Other disposal methods, as practiced in the Nigerian construction industry, are shown in Table 5 and Figure 2. Interestingly, burning is still practiced on some sites (Figure 3). Although the majority of the interviewees confirmed that they are aware of the environmental effects of burning, such as air pollution, fire disaster, and ozone layer depletion, they still could not help but continue with this illegal practice, as it is a cheaper option when compared with other methods. For example, one participant revealed: "Sometimes we burn the waste which is against the law because we don't have a choice than to burn them. Although it causes air pollution" (F5). Another interviewee confirmed, "There are some that we burn even though there is a State legislation against that" (MC1), yet the practice continues. It is obvious that awareness does not translate to action, which may indicate the lack of enforcement in the Nigerian construction industry. Another disposal method that is worthy of mention is re-sell. As confirmed by some of the interviewees, material wastes are sold to interested member of the public, which is a form of reuse. One of the interviewees noted: " .. most time what we do is to sell some of the fossil materials that we know we can't reuse. We sell them or even give them out to people who use them as fossil fuels" (E7). 
Table 5. Disposal methods, as indicated by the questionnaire survey.

\begin{tabular}{ccc}
\hline Disposal methods & Frequency & Percentage \\
\hline Open dumping & 43 & 17.7 \\
Recycling & 53 & 21.8 \\
Landfilling & 57 & 23.5 \\
Incineration & 18 & 7.4 \\
Reuse as backfill & 54 & 22.2 \\
Onsite dig and bury & 11 & 4.5 \\
Burning & 7 & 2.9 \\
Total & 243 & 100.0 \\
\hline
\end{tabular}

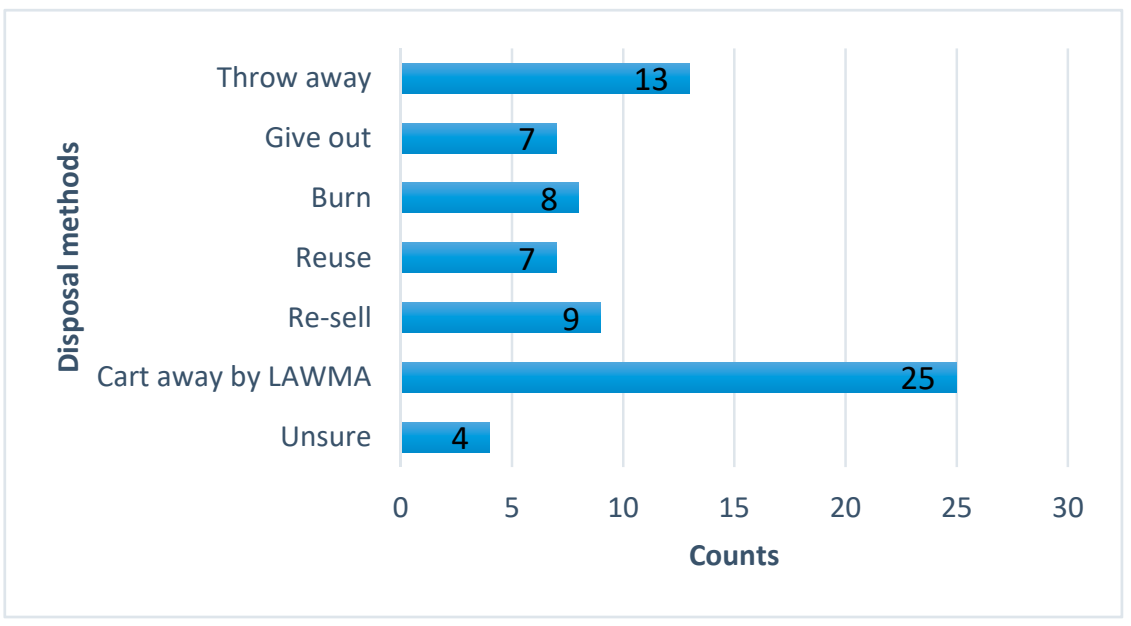

Figure 2. Disposal methods, as indicated by the interviewees.

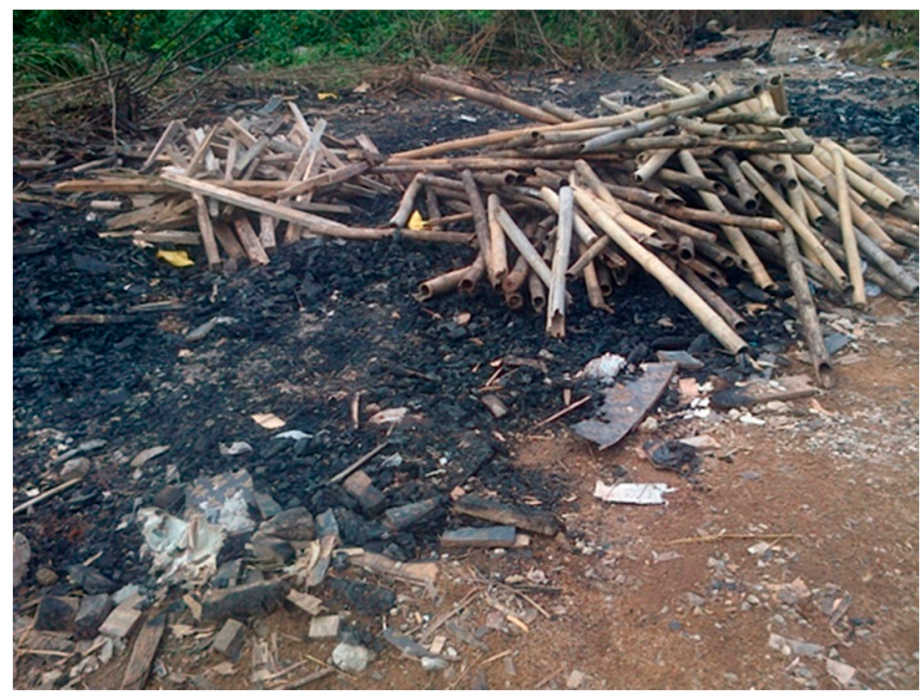

Figure 3. Evidence of burning on construction site S7. Source: Authors' field survey, 2017.

Similar to re-sell, it was identified that material wastes are given to those who are interested, which is quite common in the industry. Some material wastes are re-used as backfill for the excavated portion on same site or another. Waste materials are also used to fill pot holes on roads, while some are used to fill hollow parts of sandcrete blocks to provide strength. The open dumping of materials may cause a negative environmental impact, such as air pollution. Likewise, the practice of on-site dig and the burying of materials: digging a portion of the site and burying waste materials, may contaminate drinking water, cause erosion, and kill vegetation. 
The findings of this study identify that the availability of land and lack of regulatory policies may be responsible for landfilling. Although wastes that are dumped in landfills may be converted to energy, this has yet to be fully explored in Nigeria. As suggested by Olorunfemi [77], landfills in Lagos may exceed their capacity in the near future if the disposal rate remains consistent. The finding has implications for practice, industry, and government policy. Construction professionals need to change the misconception that landfilling is a cheaper option when compared to reuse and recycling. The design team has to adopt effective design minimisation measures, while other professionals are to ensure efficient waste reduction approaches. Therefore, they need to encourage the sorting and segregation of material wastes on site to enhance reuse and recycling. Through sustainable disposal options, the industry may engage in industrial symbiosis where the material wastes generated will serve as resource and they are exchanged with other industries and vice versa. For example, material wastes from the agricultural industry may serve as raw materials for some products in the construction industry. Likewise, the industry may take advantage of the low recycling rate in the country and invest into recycling of construction materials, which is less competitive. Awareness and education regarding appropriate waste management, including collection and disposal, is essential for all construction workforces and should be provided by firms, in conjunction with the industry.

The existing waste management policy in Nigeria that is closely related to the construction industry is the National Environmental (construction sector) regulations [78]. This regulation lacks specificity and its provisions are ambiguous [79]. The government may consider measures, such as the introduction of regulatory policy, including site waste management plan (SWMP), Pay-As-You-Throw (PAYT), and landfill ban to divert material wastes from landfills. The SWMP, as a regulation, was adopted in the UK in 2008. It provides minimisation and management measures, while identifying the types and potential waste sources [28]. A study by Oladiran [63] found that SWMP has substantial effect on material waste minimisation. PAYT is a pay per unit volume of waste generated and its purpose is to reduce waste and encourage reuse and recycling. Brown \& Johnstone [80] and Dahlén \& Lagerkvist, [81] revealed that it has been effective in reducing waste that is sent to landfills. Landfill ban is an outright ban on disposal of construction waste to the landfill. A study by Scharff [82] found that landfill bans, taxes, and regulations had a massive impact in reducing waste in the Netherlands. Although the enforcement and monitoring of policies in Nigeria have been reported to be poor $[52,70,83]$, there are other options that may be introduced at a government level to improve waste practice: introduction of incentives, recognition, and awards for the best waste management practices to motivate and encourage construction professionals and firms that may improve compliance. The finding of this study aligns with previous research $[52,84,85]$, which revealed landfilling to be the most preferred method of waste disposal in Nigeria. As a way to deter continuous landfilling, the current waste disposal levy may be increased, while the government makes provisions for recycling plants. This finding is not surprising, because it was clearly evident during the researchers' field work in Lagos that wastes are sent to landfills, which is also a global problem, as formerly identified. The issue of landfilling is not only specific to developing countries; therefore, this study suggests the need to reduce wastes that are sent to landfills by encouraging the sorting and segregation of materials that are reusable and recyclable. For ease of reuse and recycling, different skips may be provided, while the construction workforce is trained to identify and place materials in appropriate skips.

\subsection{Disposal Methods and Company Characteristics}

The relationship between company's characteristics and disposal methods was explored to identify any causal relationship or association (Table 6). The findings revealed no association between the company's ownership status and disposal methods $(\chi 2(18)>=19.080, p=0.387)$. Similarly, it was revealed that there is no association between a company's age and disposal methods $(\chi 2(24)>=$ $26.605, p=0.323)$; or, company's main construction activity and disposal methods $(\chi 2(18)>=21.428$, $p=0.258)$. However, there was a significant association between the company's size and disposal methods $(\chi 2(18)=25.121, p=0.014)$. 
Table 6. Association between methods and company's characteristics.

\begin{tabular}{cccc}
\hline \multirow{2}{*}{ Cross Tabulation } & \multicolumn{3}{c}{ Chi-Square Tests } \\
\cline { 2 - 4 } & Value & df & $p$-Value \\
\hline Disposal method and company ownership status & $19.080^{\mathrm{a}}$ & 18 & 0.387 \\
Disposal method and Company age & $26.605^{\mathrm{b}}$ & 24 & 0.323 \\
Disposal method and Company size & $25.121^{\mathrm{c}}$ & 12 & 0.014 \\
Disposal method and Company's main construction activity & $21.428^{\mathrm{d}}$ & 18 & 0.258 \\
\hline
\end{tabular}

a: 15 cells (53.6\%) have expected count less than 5 . The minimum expected count is $0.52{ }^{\text {b }}: 15$ cells (42.9\%) have expected count less than 5 . The minimum expected count is 0.98 . c : 6 cells $(28.6 \%)$ have expected count less than 5 . The minimum expected count is $1.73 .{ }^{\mathrm{d}}: 21$ cells $(75.0 \%)$ have expected count less than 5 . The minimum expected count is 0.12 .

Based on the result, it may be concluded that the company size is associated with material waste disposal methods. It is noted that small sized companies prefer reuse as backfill, landfilling, open dumping, and recycling in that order than incineration, onsite dig and bury, and burning. Interestingly, large sized firms prefer incineration, onsite dig and bury, and burning, respectively, rather than other disposal methods that were identified in this study (Table 7).

The findings imply that waste disposal methods among construction firms vary, which may depend on technology, equipment, personnel, and financial capacity. For instance, small sized firms may lack the type of equipment that is used by a large sized firm. From the findings, it is clear that small sized firms reuse wastes as backfill more than other disposal methods, and the reason may be the need to avoid cost overrun and maintaining maximum profit. Large sized firms were found to prefer onsite dig and bury and burning, which may indicate non-commitment to their community social responsibility and non-compliance to State laws. They are reluctant to adopt reuse or recycling methods, because there are no laws or regulations forcing them to do so, as stated by some of the interviewees. Other reasons are corruption and unethical practices.

The findings of this study have implications in industry, practice, and policy. It provides a valuable reference for firms and industry to prioritise the environment rather than profit when thinking and deciding on disposal methods. In the current climate, there is a need to address the issue of waste production as well as design. Although waste is mostly generated during construction, if minimised in the first instance, then it may be easy to effectively manage the residue. Hence, the need to consider minimising waste through design. Professionals need to work out ways of reducing wastes as much as possible to divert them from landfill. By designing out waste, design professionals may be able to minimise waste, while other professionals may adopt green procurement and construction, including just-in-time delivery, prefabrication, and off-site construction.

The relevance for policies is that government may device a means to enforce regulatory policies and enhance compliance, such as incentives and penalty schemes. Likewise, policies that require construction firms to provide waste management plan, which includes disposal methods, may be formulated and properly monitored to ensure strict adherence. The findings of this research compare differently to previous studies $[86,87]$, which found large scale firms to exhibit positive attitudes to waste management. No study in Nigeria has previously investigated the association between firms and waste disposal methods, which is the novelty of this study. Therefore, it is important for all sizes of firms to dispose material wastes in the best environmental way possible, while the circular economy concept through the $3 \mathrm{R}$ principle (reduce, reuse, and recycling) may be adopted for effective management. 
Table 7. Cross tabulation of disposal methods and company size.

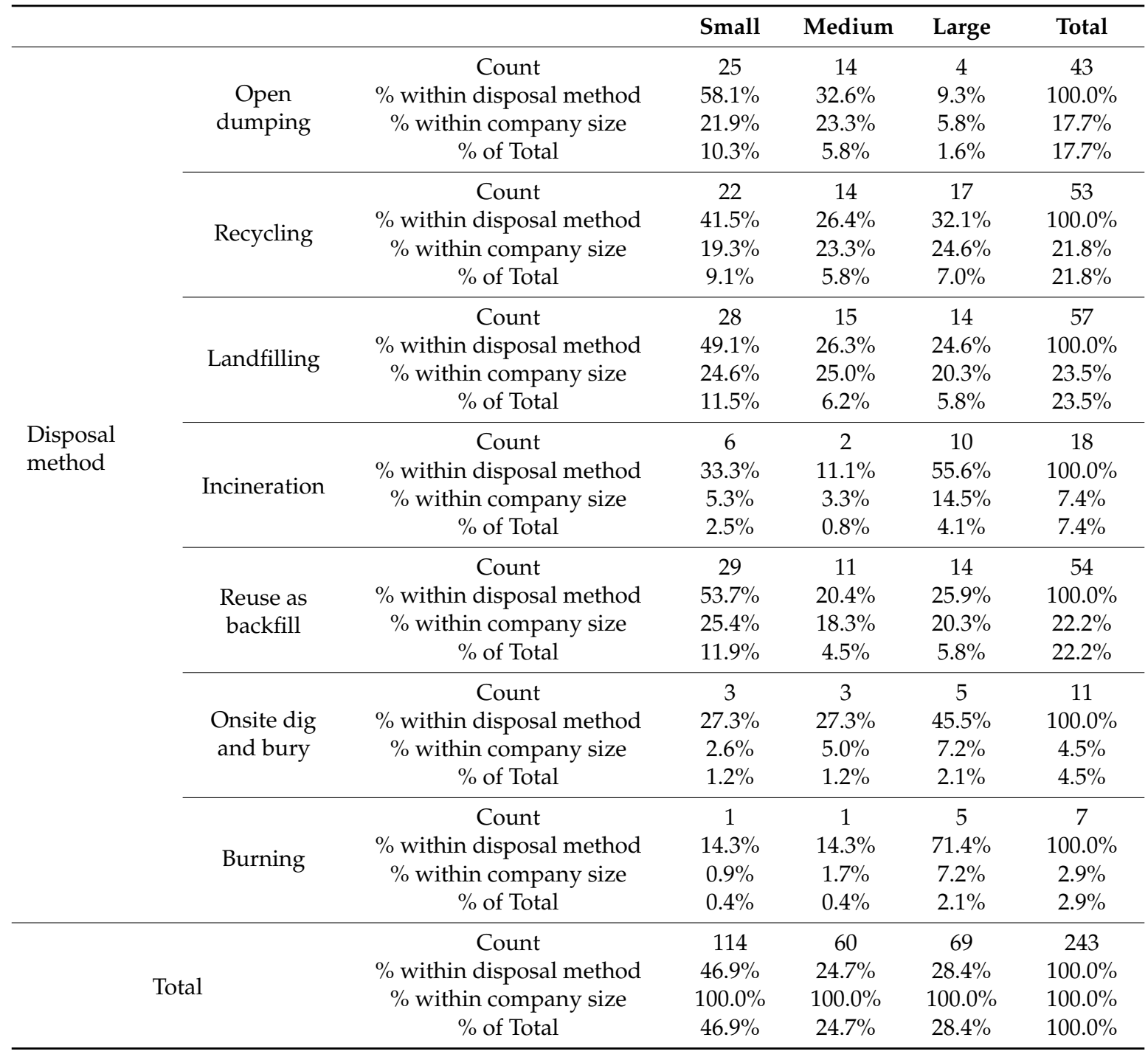

\section{Conclusions and Recommendations}

Using a convergent parallel mixed methods, this study has examined material waste disposal methods in the Nigerian construction industry. The study was conducted in Lagos to present the status quo of construction waste disposal in Nigeria. Waste management measures and disposal methods, including reuse, recycling, incineration, composting, landfilling, open dumping, and burning were reviewed. The following conclusions can be drawn based on the findings:

1. The main waste disposal method in the $\mathrm{NCI}$ is landfilling.

2. When compared to other firm's characteristics (ownership status, age, project specialisation), there is a significant relationship between a firm's size and the disposal methods that they adopt.

3. Large firms adopt incineration, burying, and burning, while small firms adopt reuse as backfill, landfilling, open dumping, and recycling.

4. Burning is still practiced in the NCI despite environmental legislation against it.

Based on these findings, the status quo of waste disposal in Lagos has remained over the years, which suggests the need to adopt effective minimisation methods. In addition, there is need for improvement in construction waste management to prevent further environmental degradation. There is also a need to change industry culture to promote the awareness and understanding of this important 
issue. Recommendation for future study stress the need to include other construction workforce and stakeholders to develop a holistic waste disposal framework. Finally, this study offers new insights into the use of concurrent triangulation mixed methods approach in construction management research, especially in Nigeria.

Author Contributions: Conceptualisation, O.E.O.; methodology, O.E.O.; formal analysis, O.E.O.; investigation, O.E.O., W.S., and K.M.; resources, O.E.O.; data curation, O.E.O.; writing-original draft preparation, O.E.O.; writing - review and editing, W.S. and K.M.; supervision, W.S. and K.M.

Funding: UNIPRS and UNRSC50:50.

Acknowledgments: This paper forms part of the lead author's PhD research supported by the University of Newcastle International Postgraduate Research Scholarship (UNIPRS) and University of Newcastle Research Scholarship Central and Faculty (UNRSC50:50). Contributions of supervisors are well appreciated.

Conflicts of Interest: The authors declare no conflict of interest.

\section{References}

1. Asase, M.; Yanful, E.K.; Mensah, M.; Stanford, J.; Amponsah, S. Comparison of municipal solid waste management systems in Canada and Ghana: A case study of the cities of London, Ontario, and Kumasi, Ghana. Waste Manag. 2009, 29, 2779-2786. [CrossRef] [PubMed]

2. Esin, T.; Cosgun, N. A study conducted to reduce construction waste generation in Turkey. Build. Environ. 2007, 42, 1667-1674. [CrossRef]

3. Kofoworola, O.F.; Gheewala, S.H. Estimation of construction waste generation and management in Thailand. Waste Manag. 2009, 29, 731-738. [CrossRef] [PubMed]

4. Saraiva, T.S.; Borges, M.M.; Filho, A.C. The Importance of Recycling of Construction and Demolition Waste. In Proceedings of the PLEA2012-28th Conference, Opportunities, Limits \& Needs towards an Environmentally Responsible Architecture, Lima, Perú, 7-9 November 2012.

5. Al-Hajj, A.; Hamani, K. Material Waste in the UAE Construction Industry: Main Causes and Minimisation Practices. Archit. Eng. Des. Manag. 2011, 7, 221-235. [CrossRef]

6. Arponen, J.; Granskog, A.; Pantsar, M. The Opportunities of a Circular Economy for Finland; Sitra: Helsinki, Finland, 2015.

7. Viljoen, A. Quality Factors Contributing to the Generation of Construction Waste. Master's Thesis, Cape Peninsula University of Technology, Cape Town, South Africa, 2010.

8. Ekanayake, L.L.; Ofori, G. Construction material waste source evaluation. In Proceedings of the Second Southern African Conference on Sustainable Development in the Built Environment: Strategies for a Sustainable Built Environment, Pretoria, South Africa, 23-25 August 2000.

9. Osmani, M.; Glass, J.; Price, A.D.F. Architects' perspectives on construction waste reduction by design. Waste Manag. 2008, 28, 1147-1158. [CrossRef]

10. Garba, A.; Olaleye, Y.O.; Jibrin, N.S. Material Resources Optimization for Sustainable Construction in Nigeria. J. Eng. Archit. 2016, 4, 33-47. [CrossRef]

11. Watuka, J.; Aligula, E.M. Sustainable Construction Practices in the Kenyan Construction Industry: The Need for a Facilitative Regulatory Environment. In Proceedings of the CIB W107 1st International Conference: Creating a Sustainable Construction Industry in Developing Countries, Stellenbosch, South Africa, 11-13 November 2002.

12. Nwokoro, I.; Onukwube, H. Sustainable or Green Construction in Lagos, Nigeria: Principles, Attributes and Framework. J. Sustain. Dev. 2011, 4, 166. [CrossRef]

13. Zuo, J.; Zhao, Z.Y. Green building research-current status and future agenda: A review. Renew. Sustain. Energy Rev. 2014, 30, 271-281. [CrossRef]

14. Enshassi, A.; Mohamed, S.; Abushaban, S. Factors Affecting the Performance of Construction Projects in the Gaza Strip. J. Civ. Eng. Manag. 2009, 15, 269-280. [CrossRef]

15. Adewuyi, T.O. Construction Material Waste Planning and Control Techniques on Building Sites in South-South of Nigeria. Ph.D. Thesis, Department of Building, Faculty of Environmental Studies, University of Uyo, Uyo, Nigeria, 2012. 
16. Dajadian, S.A.; Koch, D.C. Waste Management Models and Their Applications on Construction Sites. Int. J. Constr. Eng. Manag. 2014, 3, 91-98.

17. Garas, G.L.; Anis, A.R.; Gammal, A.E. Materials waste in the Egyptian construction Industry. In Proceedings of the IGLC-9, Rent Ridge Crescent, Singapore, 6-8 August 2001.

18. Polat, G.; Ballard, G. Waste in Turkish Construction- Need for Lean Construction Techniques. In Proceedings of the 12th Annual Conference of the International Group for Lean Construction IGLC-12, Helsingør, Denmark, 3-6 August 2004; pp. 488-501.

19. Poon, C.S.; Yu, A.T.W.; Ng, L.H. A Guide for Managing and Minimizing Building and Demolition Waste; The Hong Kong Polytechnic University: Hong Kong, 2001.

20. Al-Moghany, S.S. Managing and Minimizing Construction Waste in Gaza Strip. Master's Thesis, The Islamic University of Gaza, Gaza City, Palestine, 2006.

21. Odusami, K.T.; Oladiran, O.J.; Ibrahim, S.A. Evaluation of Materials Wastage and Control in some selected Building sites in Nigeria. Emir. J. Eng. Res. 2012, 17, 53-65.

22. Ajayi, S. Design, Procurement and Construction Strategies for Minimizing Waste in Construction Projects. Ph.D. Thesis, University of the West of England, Bristol, UK, 2017.

23. Mata, T.M.; Mendes, A.M.; Caetano, N.S.; Martins, A.A. Sustainability and economic evaluation of microalgae grown in brewery wastewater. Bioresour. Technol. 2014, 168, 151-158. [CrossRef] [PubMed]

24. Nagapan, S.; Rahman, I.A.; Asmi, A. Factors contributing to physical and non-physical waste generation in construction industry. Int. J. Adv. Appl. Sci. 2012, 1, 1-10. [CrossRef]

25. Shen, L.Y.; Tam, W.Y.V.; Tam, C.M.; Drew, D. Mapping approach for examining waste management on construction sites. J. Constr. Eng. Manag. 2004, 130, 472-481. [CrossRef]

26. Rodgers, M. Fundamentals of Development Administration; S.K. Publishers: London, UK, 2011.

27. Ekanayake, L.L.; Ofori, G. Building Waste Assessments Score: Design based tool. Build. Environ. 2004, 39, 851-861. [CrossRef]

28. Greenwood, R. Construction Waste Minimisation: Good Practice Guide; Centre for Research in the Built Environment, Cardiff University: Cardiff, Wales, 2003.

29. Geng, Y.; Fu, J.; Sarkis, J.; Xue, B. Towards a national circular economy indicator system in China: An evaluation and critical analysis. J. Clean. Prod. 2012, 23, 216-224. [CrossRef]

30. Preston, F. A Global Redesign: Shaping the Circular Economy; Chatham House: London, UK, 2012.

31. Ghisellini, P.; Cialani, C.; Ulgiati, S. A review on circular economy: The expected transition to a balanced interplay of environmental and economic systems. J. Clean. Prod. 2016, 114, 11-32. [CrossRef]

32. United States Environmental Protection Agency (EPA); Municipal and Industrial Waste Division. Decision-Makers' Guide to Solid Waste Management, Volume II. 1995. Available online: http://www. epa.gov / epaoswer/non-hw/muncpl/dmg2/chapter8.pdf (accessed on 12 December 2018).

33. Seo, S.; Aramaki, T.; Hwang, Y.; Hanaki, K. Environmental impact of solid waste treatment methods in Korea. J. Environ. Eng. 2004, 130, 81-89. [CrossRef]

34. Kamalan, H.; Sabour, M.; Shariatmadari, N. A Review on Available Landfill Gas Models. J. Environ. Sci. Technol. 2011, 4, 79-92. [CrossRef]

35. Den Hollander, M.C.; Bakker, C.A.; Hultink, E.J. Product design in a circular economy: Development of a typology of key concepts and terms. J. Ind. Ecol. 2017, 21, 517-525. [CrossRef]

36. Ajie, U.E.; Dienye, A. Spatial Data Analysis of Solid Waste Management System in Port Harcourt Metropolis after 100 years of its Existence. In Proceedings of the FIG Congress 2014: Engaging the Challenges-Enhancing the Relevance, Kuala Lumpur, Malaysia, 16-21 June 2014.

37. Van den Berg, M.R.; Bakker, C.A. A product design framework for a circular economy. In Proceedings of the PLATE Conference, Nottingham, UK, 17-19 June 2015.

38. Shi, L.; Xing, L.; Bi, J.; Zhang, B. Circular economy: A new development strategy for sustainable development in China. In Proceedings of the 3rd World Congress of Environmental and Resource Economists, Kyoto, Japan, 3-7 July 2006.

39. Su, B.; Heshmati, A.; Geng, Y.; Yu, X. A review of the circular economy in China: Moving from rhetoric to implementation. J. Clean. Prod. 2013, 42, 215-227. [CrossRef]

40. Jun, H.; Xiang, H. Development of circular economy is a fundamental way to achieve agriculture sustainable development in China. Energy Procedia 2011, 5, 1530-1534. [CrossRef] 
41. Bartl, A. Withdrawal of the circular economy package: A wasted opportunity or a new challenge? Waste Manag. 2015, 44. [CrossRef] [PubMed]

42. Moreno, M.; Braithwaite, N.; Cooper, T. Moving beyond the circular economy. In Proceedings of the Going Green-CARE Innovation, Vienna, Austria, 17-20 November 2014.

43. European Commission. Directive 2008/98/EC of the European Parliament and of the Council of 19 November 2008 on waste and repealing certain Directives. Off. J. Eur. Union 2008, 312, 3-10.

44. Ezeigwe, C. Appropriate solid waste disposal methods for developing countries. Nse Tech. Trans. 1995, 32, 33-34.

45. Charnpetheep, K.; Zhou, Q.; Garner, B. Preliminary landfill site screening using fuzzy Geographical Information System. Waste Manag. Res. 1997, 15, 197-215. [CrossRef]

46. Ajani, O.I.Y. Determinants of an effective solid waste management in Ibadan Metropolis Oyo State, Nigeria. J. Food Agric. Environ. 2007, 6, 152-157.

47. Igoni, A.H.; Ayotamuno, M.; Ogaji, S.O.T.; Probert, S.D. Municipal solid waste in Port Harcourt, Nigeria. Appl. Energy 2007, 84, 664-670. [CrossRef]

48. Akanni, P.O. An Empirical Survey of the Effect of Materials Wastage on Contractors' Profit Level in Construction Projects. Prof. Build. J. Niger. Inst. Build. 2007, 1, 35-46.

49. Adewuyi, T.O.; Idoro, G.I.; Ikpo, I.J. Empirical Evaluation of Construction Material Waste Generated on Sites in Nigeria. Civ. Eng. Dimens. 2014, 16, 96-103.

50. Wahab, A.B.; Lawal, A.F. An evaluation of waste control measure in construction industry in Nigeria. Afr. J. Environ. Sci. Technol. 2011, 3, 246-254.

51. Kareem, W.A.; Asa, O.A.; Lawal, M.O. Resources conservation and waste management practices in construction industry. Arab. J. Bus. Manag. Rev. (Oman Chapter) 2015, 4, 20. [CrossRef]

52. Dania, A.A.; Kehinde, J.O.; Bala, K. A Study of Construction Material Waste Management Practices by Construction Firms in Nigeria. In Proceedings of the 3rd Scottish Conference for Postgraduate Researchers of the Built and Natural Environment, Glasgow, UK, 20-22 November 2007; pp. 121-129.

53. Ogwueleka, T.C. Municipal Solid Waste Characteristics and Management in Nigeria Iran. J. Env. Health Sci. 2009, 6, 173-180.

54. Ganiyu, S.A.; Ogunmakinde, O.E.; Oladokun, S.D. Managing Waste in Construction Site, in Akure, Ondo State. In Proceedings of the Joint International Conference (JIC) on 21st Century Human Habitat: Issues, Sustainability and Development, Akure, Nigeria, 21-24 March 2016; pp. 215-223.

55. LAWMA. Landfill-Monthly Dump Reports 2014. Available online: http://www.lawma.gov.ng/insidelawma/departments/landfill/ (accessed on 20 January 2019).

56. Igbinomwanhia, D.I. Status of waste management. In Integrated Waste Management-Volume II; InTech: London, UK, 2011.

57. Obadina, A. Solid Waste Management Livelihood on Lagos Dumpsite: Analysis of Gender and Social Difference. Ph.D. Thesis, Loughborough University, Loughborough, UK, 2016.

58. Odewumi, S.G. Appraisal of storage and collection strategies of municipal solid waste in Lagos State. J. Humanit. Soc. Sci. 2013, 10, 61-67. [CrossRef]

59. Kofoworola, O.F. Comparative assessment of the environmental implication of management options for municipal solid waste in Nigeria. Int. J. Waste Resour. 2016, 7, 1-5. [CrossRef]

60. Ajanlekoko, A.S. Sustainable housing development in Nigeria: The financial infrastructural implication. In Proceedings of the International Conference on Spatial Information for Sustainable Development, Nairobi, Kenya, 2-5 October 2001; pp. 1-13.

61. NIOB. Facilities Management for Sustainable Building Performance. In Proceedings of the 2-days National Seminar Organized by the Nigerian Institute of Building (NIOB), Lafia, Nigeria, 27-28 April 2005.

62. Creswell, J.W.; Plano Clark, V.L.; Gutmann, M.L.; Hanson, W.E. Advanced mixed methods research designs. In Handbook of Mixed Methods in Social and Behavioural Research; Sage Publications: Thousand Oaks, CA, USA, 2003; pp. 209-240.

63. Oladiran, O.J. Causes and Minimization Techniques of Materials Waste in Nigerian Construction Process. In Proceedings of the Fifth International Conference on Construction in the 21st Century (CITC-V), Istanbul, Turkey, 20-22 May 2009; pp. 20-22.

64. Saidu, I.; Winston, S. The contributions of construction material waste to project cost overruns in Abuja, Nigeria. Acta Structilia 2016, 23, 99-113. [CrossRef] 
65. Cochran, W.G. Experimental Designs; Wiley Publications in Applied Statistics: New York, NY, USA, 1983.

66. Oladapo, A.A. A quantitative assessment of the cost and time impact of variation orders on construction projects. J. Eng. Des. Technol. 2007, 5, 35-48. [CrossRef]

67. Olaleye, F.; Abdullah, M. Influence of Information Technology on the Performance of Small and Medium sized Construction Firms in Nigeria. Res. J. Bus. Manag. Account. 2014, 3, $21-27$.

68. Odediran, S.J.; Adeyinka, B.F.; Opatunji, O.A.; Morakinyo, K.O. Business Structure of Indigenous Firms in the Nigerian Construction Industry. Int. J. Bus. Res. Manag. 2012, 3, 255-264.

69. Bhattacherjee, A. Social Science Research: Principles, Methods, and Practices; Global Text Project: Athens, Georgia, 2012.

70. Chinyio, E.A.; Olomolaiye, P.O. A needs based methodology for classifying construction clients and selecting contractors-a rejoinder. Constr. Manag. Econ. 1999, 17, 413-417. [CrossRef]

71. Akintoye, A. Analysis of factors influencing project cost estimating practice. Constr. Manag. Econ. 2000, 18, 77-89. [CrossRef]

72. Dulaimi, M.F.; Ling, F.Y.; Bajracharya, A. Organizational motivation and inter-organizational interaction in construction innovation in Singapore. Constr. Manag. Econ. 2003, 21, 307-318. [CrossRef]

73. Takim, R.; Akintoye, A.; Kelly, J. Analysis of performance measurement in the Malaysian construction industry. In Proceedings of the Globalization and Construction, AIT Conference Centre, Bangkok, Thailand, 17-19 November 2004.

74. Tam, V.W. The effectiveness of the green building evaluation and labelling system. Archit. Sci. Rev. 2007, 50, 323-330. [CrossRef]

75. Chinowsky, P.S.; Meredith, J.E. Strategic management in construction. J. Constr. Eng. Manag. 2000, 126, 1-9. [CrossRef]

76. Fahmy, A.; Hassan, T.M.; Bassioni, H. Improving RCPSP solutions quality with Stacking Justification-Application with particle swarm optimization. Expert Syst. Appl. 2004, 41, 5870-5881. [CrossRef]

77. Olorunfemi, F.B. Landfill development and current practices in Lagos metropolis, Nigeria. J. Geogr. Reg. Plan. 2011, 4, 656 .

78. The National Environmental Standards and Regulations Enforcement Agency (NESREA). Available online: http:/ / www.nesrea.gov.ng/about/index.php (accessed on 12 December 2018).

79. Dania, A.A. Sustainable Construction at the Firm Level: Case Studies from Nigeria. Ph.D. Thesis, University of Reading, Reading, UK, 2017.

80. Brown, Z.S.; Johnstone, N. Better the devil you throw: Experience and support for pay-as-you-throw waste charges. Environ. Sci. Policy 2014, 38, 132-142. [CrossRef]

81. Dahlén, L.; Anders, L. Pay as you throw: Strengths and weaknesses of weight-based billing in household waste collection systems in Sweden. Waste Manag. 2010, 30, 23-31. [CrossRef] [PubMed]

82. Scharff, H. Landfill reduction experience in The Netherlands. Waste Manag. 2014, 34, 2218-2224. [CrossRef]

83. Akadiri, O.P. Development of a Multi-Criteria Approach for the Selection of Sustainable Materials for Building Projects. Ph.D. Thesis, University of Wolverhampton, Wolverhampton, UK, 2011.

84. Ola-Adisa, E.; Sati, Y.C.; Ojonugwa, I.I. An Architectural Approach to Solid Waste Management on Selected Building Construction Sites in Bauchi Metropolis. Int. J. Merging Eng. Res. Technol. 2015, 3, 67-77.

85. Ajayi, O.M.; Koleoso, H.A.; Soyingbe, A.A.; Oladiran, O.J. The practice of waste management in construction sites in Lagos state; Nigeria. In Proceedings of the Construction and Building Research Conference of the Royal Institution of Chartered Surveyors, Kaduna, Nigeria, 4 September 2008.

86. Abidin, N.Z. Investigating the awareness and application of sustainable construction concept by Malaysian developers. Habitat Int. 2010, 34, 421-426. [CrossRef]

87. Chang, R.D.; Zuo, J.; Zhao, Z.Y.; Soebarto, V.; Lu, Y.; Zillante, G.; Gan, X.L. Sustainability attitude and performance of construction enterprises: A China study. J. Clean. Prod. 2018, 172, 1440-1451. [CrossRef]

(C) 2019 by the authors. Licensee MDPI, Basel, Switzerland. This article is an open access article distributed under the terms and conditions of the Creative Commons Attribution (CC BY) license (http://creativecommons.org/licenses/by/4.0/). 